\title{
Efek Pupuk Bio-Kimia Realstrong Dan Pupuk Kandang Pada Pertumbuhan Dan Hasil Beta vulgaris $L$
}

\author{
Donatus Dahang ${ }^{1)}$, Sri Desi Br. Sinuhaji ${ }^{2)}$ \\ ${ }^{1) 2}$ Fakultas Pertanian, Universitas Quality, Medan, Indonesia \\ Email : donatus.tarsier.project@gmail.com
}

\begin{abstract}
Abstrak
Penelitian penggunaan pupuk kandang berbagai jenis dengan pupuk Biokimia RealStrong telah dilakukan di Lahan Desa Aji Buhara, Kecamatan Tigapanah,Kabupaten Karo,Sumatera Utara, terhitung Februari-April 2018. Penelitian ini bertujuan untuk mengetahui efek penggunaan pupuk tersebut bagi pertumbuhan dan hasil tanaman bit. Penelitian ini menggunakan rancangan acak lengkap pola factorial, faktor 1 ; Jenis Pupuk Kandang: $\mathrm{P}_{0}$ : kontrol (tanpa perlakuan), $\mathrm{P}_{1}$ : kandang ayam $1,5 \mathrm{~kg} /$ plot, dan $\mathrm{P}_{2}$ : kandang sapi $1,5 \mathrm{~kg} / \mathrm{plot}$. Factor 2, Dosis Pupuk RealStrong: $\mathrm{R}_{0}=$ kontrol (tanpa perlakuan), $\mathrm{R}_{1}=125 \mathrm{gr} /$ plot, $\mathrm{R}_{2}=250 \mathrm{gr} /$ plot, dan $\mathrm{R}_{3}=375 \mathrm{gr} /$ plot. Hasil penelitian menunjukkan efek P1 menghasilkan tinggi tanaman tertinggi yaitu rata-rata $33.88 \mathrm{~cm}$ dan $\mathrm{R} 3$ pert 34.90 $\mathrm{cm}$. Jenis dan dosis kedua jenis pupuk juga berpengaruh pada produksi tanaman bit, pupuk kandang ayam P1 menghasilkan rata-rata $101.64 \mathrm{~g} / \mathrm{sampel}$ dan pupuk bio-kimia Realstrong R3menghasilkan rata-rata $3.20 \mathrm{~kg} / \mathrm{plot}$
\end{abstract}

Kata Kunci:Beta vulgaris, Pupuk Kandang, RealStrong, Budidaya

\section{Abstract}

The research on effect of manures and biochemical RealStrong fertilizer had been done. The research was conducted at Aji BuharaVillage, Tigapanah Subdistrict,Karo Regency,North Sumatra, February to April 2018. The proposed of the study was to see the effects of the fertilizers in growing and producing of Beta vulgaris. Random cluster block design with factorial classic was applied,factor 1 ; manures: $\mathrm{P}_{0}$ : control, $\mathrm{P}_{1}$ :chicken's manures $1,5 \mathrm{~kg} /$ plot, andP $\mathrm{P}_{2}$ :caw's manures 1 , $5 \mathrm{~kg} /$ plot. Factor 2, Biochemical RealStrong fertilizers: $\mathrm{R}_{0}=$ control, $\mathrm{R}_{1}=$ $125 \mathrm{gr} / \mathrm{plot}, \mathrm{R}_{2}=250 \mathrm{gr} /$ plotandR $\mathrm{R}_{3}=375 \mathrm{gr} /$ plot. Results of the study shown that the effect of P1 had given a highest growing i.e $33.88 \mathrm{~cm}$ and(R3)34.90 cm. Kinds and dosage of the fertilizers also influence of productions of the plant. The manure P1 had given production to $101.64 \mathrm{~g} / \mathrm{sampeland}$ biochemical Realstrong R3given production of $3.20 \mathrm{~kg} / \mathrm{plot}$

Key Words:Beta vulgaris, Manures, Biochemical fertilizer, cultivation

\section{PENDAHULUAN}

Bit (Beta vulgaris L)merupakan sejenis tanaman umbi-umbian yang termasuk dalam keluarga amaranthaceae yang kaya akan gizi seperti protein, lemak, karbohidrat, serat, kalori, sodium, kalsium, besi, vit $A$, vit $B 1$, vit $C$, vit B3(Handayani, 2011). Oleh karena itu, bit sering dikonsumsi oleh masyrakat. Secara morfologi tanaman bit berwarna merah keungu- 
unguan, berbentuk bulat, lonjong dan daun berwarna hijau kemerahan.

Bit yang juga dikenal dengan nama akar bit atau umbi bit merupakan salah satu varietas Beta vulgaris. Tanaman tersebuttersebar di Amerika Utara, Eropa dan Asia, termasuk Indonesia. Karena kandungan nutrisinya bit digunakan sebagai sayuran, jus dan makanan olahan lainnya. Karena manfaat tersebut maka bit dibudidayakan secara masif di Indonesia khususnya daerah Cipanas, Lembang, Pangalengan, dan Batu (Fardiaz. 2013).

Kendati demikian tidak semua orang mengemari buah bit. Rasa dan bau tanah yang khas menyebabkan orang kurang menyukai bit. Masyarakat Indonesia mengenal bit sebagai tanaman yang memiliki banyak khasiat untukkesehatan. Bit mengandung karbohidrat yang mudah diubah menjadi energi dan zat besi. Hal ini membantu mempelancar aliran oksigen ke otak sehinga membantu kesimbangan cairan dalam tubuh. Selain itu, bit juga mengandung beberapa zat lain, di antaranya adalah asam folat yang bermanfaat bagi ibu hamil karena berperan dalam penbentukan otak bayi. Bit juga berfungsi mencegah kanker dan betasianin yang bermanfaat untuk mencegah kanker (Handayani, 2011). Oleh karena itu, kendati tidak menyukai, orang tetap mengkonsumsi bit. Beberapa cara mengkonsumsi bit antara lain diolah menjadi jus, direbus sebentar untuk saled, dibuat pure (dihaluskan) untuk sup, dan lain-lain. Kebanyakan pengolahanya dalam bentuk segar dan sederhana.

Megingat manfaatnya tersebut, maka produksi bit perlu ditingkatkan. Hinga kini produksi bit belum maksimal sehingga diperlukan penyempurnaanaspek budidayanya. Dalam melakukan budidaya tanaman bit, pemeliharaan merupakan salah satu hal yang sangat penting untuk diperhatikan. Pada pemeliharan inilah yang menentukan bagaimana kualitas bit yang dihasilkan dari tanaman tersebut. Proses pemeliharaan ini meliputi beberapa hal yaitu mengenai penyiangan, pemupukan, pengairan dan juga penanggulangan terhadap hama dan penyakit. Penyiangan dapat dilakukan dengan Pembersihan lahan dari tanaman pengganggu tanaman utama yaitu gulma. Bit banyak ditanami di dataran tinggi dengan ketinggian lebih dari $1.000 \mathrm{~m} \mathrm{dpl}$, terutama bit merah. Akan tetapi bit putih ditanam pada ketinggian $500 \mathrm{~m}$ dpl. Produksi bit mencapai \pm 10 ton per hektar. Agar produksi tanaman bit meningkat maka diperlukan pemupukan dan pemeliharan yang tepat (Meridianto, 2013). Oleh karena itu, penelitian mengenai efek pupukBio-Kimia RealStrongdan pupuk kandang padapertumbuhan dan produksi Tanaman Bitdilakukan.

\section{Tujuan Penelitian}

Penelitian ini bertujuan untuk 1) mengetahui dosis pupuk BioKimia RealStrong yang sesuai untuk pertumbuhan dan hasil tanaman bit; 2) mengetahui pengaruh jenis pupuk kandang yang tepat terhadap petumbuhan dan hasil tanaman bit; 3) mengetahui interaksi antara dosis pupuk Bio-Kimia RealStrong dengan jenis pupuk kandang.

\section{Metodologi}

Penelitian ini dilaksanakan di Lahan Desa Aji Buhara, Kecamatan Tigapanah,Kabupaten

Karo,Sumatera Utara, terhitung Februari-April 2018. Lokasi penelitian ini berada pada ketinggian 
$\pm 1250-1500$ meter dpl (Monografi Desa Aji Buhara, 2005).

Penelitian ini menggunakan Rancangan Acak Kelompok Pola Faktorial yaitu faktor 1; Jenis Pupuk Kandang: $\mathrm{P}_{0}$ : kontrol (tanpa perlakuan), $\mathrm{P}_{1}$ : kandang ayam 1,5 $\mathrm{kg} /$ plot, dan $\mathrm{P}_{2}$ : kandang sapi 1,5 $\mathrm{kg} /$ plot. Factor 2, Dosis Pupuk RealStrong: $\mathrm{R}_{0}=$ kontrol (tanpa perlakuan), $\mathrm{R}_{1}=125 \mathrm{gr} / \mathrm{plot}, \mathrm{R}_{2}=$ $250 \mathrm{gr} /$ plot, dan $\mathrm{R}_{3}=375 \mathrm{gr} / \mathrm{plot}$.

Data yang diperoleh dari hasil penelitian ini dianalisis dengan formula berikut:

\begin{tabular}{|c|c|}
\hline$Y_{i: j}$ & \\
\hline & $=\boldsymbol{\mu}+\boldsymbol{\rho}_{\mathrm{i}}+\boldsymbol{\alpha}_{\mathrm{j}}+\boldsymbol{\beta}_{\mathrm{k}}+\left(\boldsymbol{\alpha}_{\beta}\right)_{\mathrm{jk}}+\varepsilon_{\mathrm{ijk}}$ \\
\hline$Y_{i j k}$ & $\begin{array}{l}\text { pada unit percobaan dalam } \\
\text { bentuk blok ke-i dengan } \\
\text { perlakuan pemberian } \\
\text { pupuk kandang dan pupuk }\end{array}$ \\
\hline & $\begin{array}{l}\text { Bio-kimia RealStrong } \\
\text { pada taraf ke-k }\end{array}$ \\
\hline$\mu$ & :Nilai tengah \\
\hline $\mathrm{i}$ & :Efek blok ke-i \\
\hline$\alpha \mathrm{j}$ & : $\quad$ Efek dari \\
\hline & perlakuan pemberian \\
\hline & pupuk kandang dan Bio- \\
\hline & $\begin{array}{l}\text { kimia RealStrong pada } \\
\text { taraf ke-j }\end{array}$ \\
\hline$\beta \mathrm{k}$ & $\begin{array}{ccc}: & \text { Efek } & \text { dari } \\
\text { perlakuan } & \text { dosis } & \text { pupuk }\end{array}$ \\
\hline & kandang pada taraf ke-k \\
\hline
\end{tabular}

$(\alpha \beta) j \mathrm{k}$ : Efek interaksi antara pemberian pupuk kandang pada taraf ke-j dan pupuk Bio-kimia realStrong taraf ke-k.

$\varepsilon_{\mathrm{ijk}}:$ Efek error pada ulangan ke-i, perlakuan jenis pupuk kandang. pada taraf ke-j dan penggunaan dosis pupuk Bio-kimia RealStrong-k.

Uji Jarak Duncan (DMRT) pada taraf $5 \%$ digunakan untuk mendapatkan informasi adanya perbedaan antara perlakuan (Steel and Torrie,1993) jika hasil analisis sidik ragam (Anova) yang diperoleh berpengaruh sangat nyata.

\section{Hasil Dan Pembahasan}

Hasil penelitian ini menunjukkan terdapat perbedan yang nyata $(\mathrm{p}<$ 0.05).Berdasarkan analisa statistik dan Duncan' testadalah sebagai berikut:

\section{a. Tinggi tanaman (cm)}

Setelah dilakukan pengamatan selama enam minggu dengan interval 1 minggu dan dilakukan analisis terhadap pertambahan tinggi tanaman, diperoleh data yang disajikan pada Tabel 1 berikut.

Tabel 1. Rata-rata Tinggi Tanaman $\operatorname{Bit}(\mathrm{cm})$ dari Pengaruh pupuk kandang dan dosis pupuk RealStrong pada $2-6 \mathrm{mst}$

\begin{tabular}{cccccc}
\hline Perlakuan & $2 \mathrm{mst}$ & $3 \mathrm{mst}$ & $4 \mathrm{mst}$ & $5 \mathrm{mst}$ & $6 \mathrm{mst}$ \\
\hline \multicolumn{5}{c}{ Kandang } \\
P0 & $10.02 \mathrm{a}$ & $12.89 \mathrm{a}$ & $15.89 \mathrm{~b}$ & $23.97 \mathrm{~b}$ & $29.96 \mathrm{~b}$ \\
P1 & $11.08 \mathrm{a}$ & $14.12 \mathrm{a}$ & $17.55 \mathrm{a}$ & $27.32 \mathrm{a}$ & $33.88 \mathrm{a}$ \\
P2 & $11.35 \mathrm{a}$ & $13.86 \mathrm{a}$ & $17.25 \mathrm{a}$ & $26.13 \mathrm{ab}$ & $33.01 \mathrm{ab}$ \\
\hline \multicolumn{6}{c}{ Realstrong } \\
R0 & $10.44 \mathrm{a}$ & $12.91 \mathrm{a}$ & $15.17 \mathrm{~b}$ & $23.17 \mathrm{~b}$ & $28.59 \mathrm{c}$ \\
R1 & $9.54 \mathrm{a}$ & $12.54 \mathrm{a}$ & $16.67 \mathrm{ab}$ & $25.01 \mathrm{ab}$ & $31.26 \mathrm{bc}$ \\
R2 & $11.62 \mathrm{a}$ & $14.42 \mathrm{a}$ & $17.70 \mathrm{a}$ & $27.50 \mathrm{a}$ & $34.38 \mathrm{ab}$ \\
R3 & $11.66 \mathrm{a}$ & $14.63 \mathrm{a}$ & $18.05 \mathrm{a}$ & $27.56 \mathrm{a}$ & $34.90 \mathrm{a}$ \\
\hline
\end{tabular}

Huruf yang sama pada kolom yang sama berbeda tidak nyatapada taraf $5 \%$ 
Pengaruh pupuk kandang terhadap pertumbuhan tinggi tanaman pada 2-3 mst tidak berpengaruh nyata, tetapi pada 4-6 mst berbeda nyata.Tabel 1.memperlihatkan pupuk kandang ayam (P1) menghasilkan tinggi tanaman yang tertinggi dengan rata-rata $33.88 \mathrm{~cm}$ yang berbeda tidak nyata dengan pupuk kandang sapi (P2) dengan rata-rata $33.01 \mathrm{~cm}$ tetapi nyata terhadap kontrol yang memiliki tinggi rata-rata $29.96 \mathrm{~cm}$.

Pertumbuhan tinggi tanaman bit sejak 2 mst sampai 6 mst serta perubahan tinggi tanaman masingmasing perlakuan dapat dilihat pada Gambar 1.

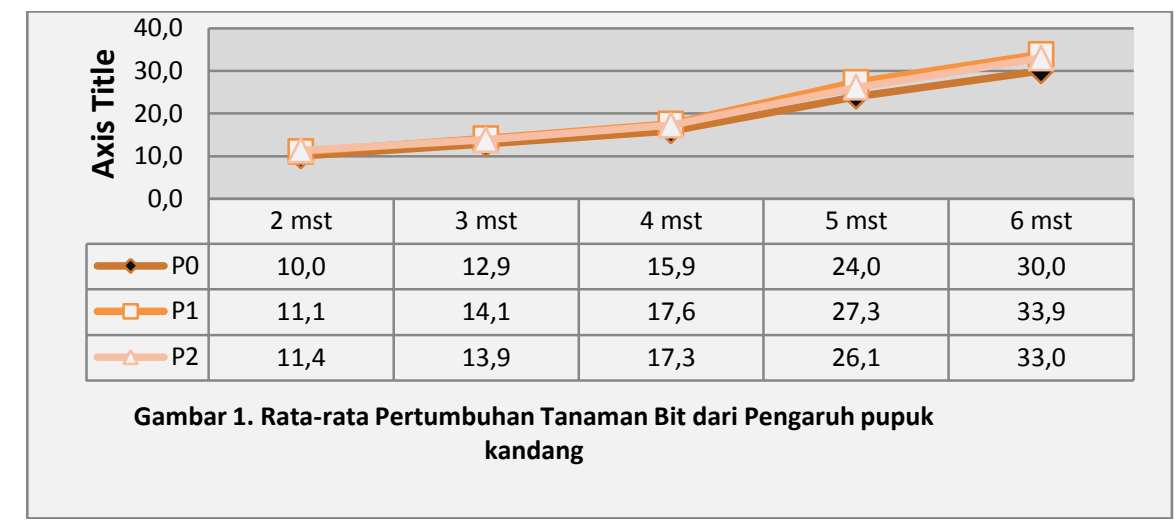

Dari hasil perhitungan rata-rata tinggi tanaman bit dari pengaruh dengan tanpa pupuk dapat dilihat pupuk kandang dibandingkan pada Gambar 1.

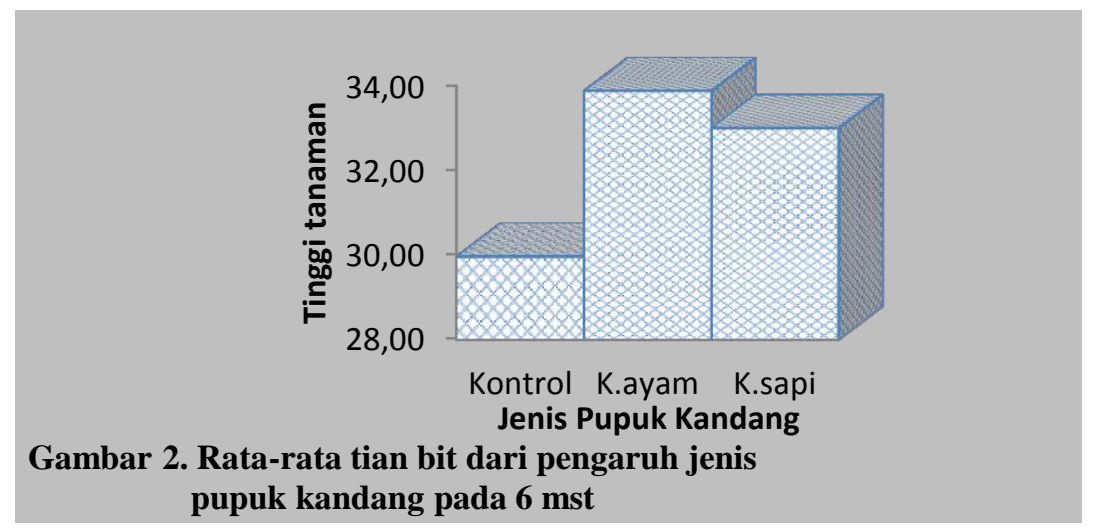

Data dari hasil pengamatan pertumbuhan tinggi tanaman bit (Tabel 1) dari pengaruh penggunaan dosis pupuk bio-kimia RealStrong(R) dilakukan sejak 2 mst meningkat pertumbuhan sampai 6 mst, hal ini terlihat perkembangan tinggi tanaman selama 6 minggu dapat dilihat pada Gambar 3. 


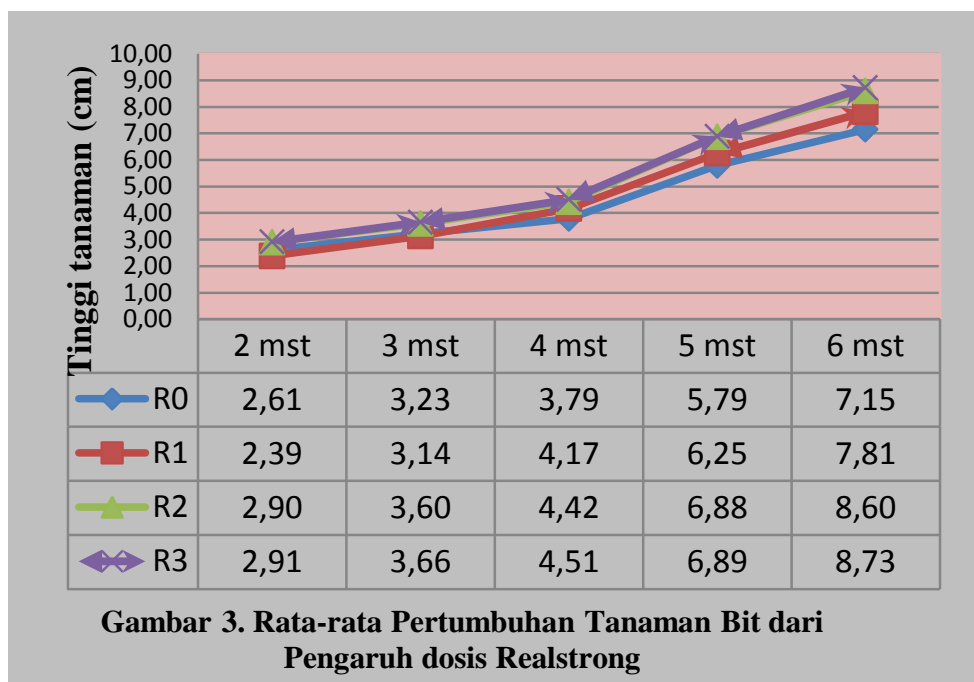

Penggunaan dosis pupuk organik bio-kimia Realstrong (R) terlihat berpengaruh pada pertumbuhan tinggi tanaman saat mulai pada 4 mst yang berbeda nyata brdasarkan analisa statistik $(\mathrm{p}<0.05)$. Pengaruhnya pupuk bio-kimia RealStrongsemakin jelas pada minggu ke 6 , seperti yang terlihat pada pengamatan 6 mst. Dosis pupuk bio-kimia RealStrong pada dosis $375 \mathrm{~g} /$ plot (R3) pertumbuhan tinggi tanaman paling tinggi ratarata $34.90 \mathrm{~cm}$, dengan berbeda tidak nyata terhadap penggunaan 250 g/plot (R2) rata-rata $34.38 \mathrm{~cm}$, tetapi berbeda nyata terhadap R1 dan R0. Tanpa perlakuan (R0) pertumbuhan tinggi tanaman paling rendah rata-rata $28.59 \mathrm{~cm}$ dengan berbeda tidak nyata terhadap R1 $(125 \mathrm{~g} / \mathrm{plot})$ tetapi berbeda nyata terhadap R2 dan R3. Dari hasil ini diperoleh bahwa penggunaan 250 g/plot (R2) telah mampu meningkatkan pertumbuhan tinggi tanaman bit di lapangan.

Perlakuan kombinasi penggunaan pupuk kandang dengan pupuk biokimia Realstrong (PR)terhadap tinggi tanaman menunjukkan perbedaan yang tidak nyata ( $\mathrm{p}<$ 0.05 ), hal ini terjadi akibat dari kedua faktor yang diujikan memberi pengaruh dalam pemberian unsur hara pada tanaman melalui pemberian pemupukan, dengan kata lain kedua faktor mendukung antara satu faktor dengan faktor kedua.

\section{b. Produksi umbi bit (g/sampel)}

Produksi dari hasil penimbangan (g/sampel) bit dilakukan saat panen dengan cara penimbangan masingmasing umbi sampel untuk semua plot perlakuan. Produksi bit (g/sampel dari pengaruh pupuk kandang (P) dan dosis pupuk biokimia ( $\mathrm{R}$ ) memberikan pengaruh yang berbeda nyata $(\mathrm{p}>0.05)$ berdasarkan analisa statistik dan Duncan' Test dapat dilihat pada Tabel 3.

Dari Tabel 2. Dapat dilihat bahwa pupuk kandang ayam (P1) merupakan produksi (g/sampel) paling tinggi dengan rata-rata $101.64 \mathrm{~g} / \mathrm{sampel}$ dengan berbeda tidak nyata $(\mathrm{p}>0.05)$ terhadap penggnaan pupuk kanang sapi (P2) rata-rata $99.02 \mathrm{~g} / \mathrm{sampel}$, tetapi berbeda nyata terhadap kontrol (P0) rata-rata produksi $89.89 \mathrm{~g} / \mathrm{sampel}$. Jika dilihat pada kontrol (P0) merupakan produksi/sampel paling rendah dengan berbeda nyata terhadap P1 tetapi tidak berbeda nyata terhadap P2. Artinya untuk 
mendapatkan produksi rata- kandang ayam (P1) dengan dosis rata/sampel dapat menggunakan $1.5 \mathrm{~kg} / \mathrm{plot}$. pupuk kandang sapi (P2) atau

Tabel 2. Rata-rata berat Bit/sampel dari Pengaruh Dosis Pupuk Kandang dan Bio-Kimia RealStrongpada saat panen.

\begin{tabular}{ccccc|}
\hline Perlakuan & Po & P1 & P2 & Rata-rata \\
\hline R0 & 80.73 & 91.07 & 85.54 & $85.78 \mathrm{c}$ \\
R1 & 84.98 & 98.09 & 98.25 & $93.77 \mathrm{bc}$ \\
R2 & 91.71 & 109.38 & 108.34 & $103.14 \mathrm{ab}$ \\
R3 & 102.16 & 108.03 & 103.94 & $104.71 \mathrm{a}$ \\
\hline Rata-rata & $89.89 \mathrm{~b}$ & $101.64 \mathrm{ab}$ & $99.02 \mathrm{a}$ & \\
\hline
\end{tabular}

Huruf yang sama pada kolom rata-rata dan baris rata-rata yang berbeda tidak nyata pada taraf $5 \%$.

Penggunaan pupuk kandang perbedaan ini dapat dilihat pada memberi respon yang berbeda terhadap produksi/sampel,

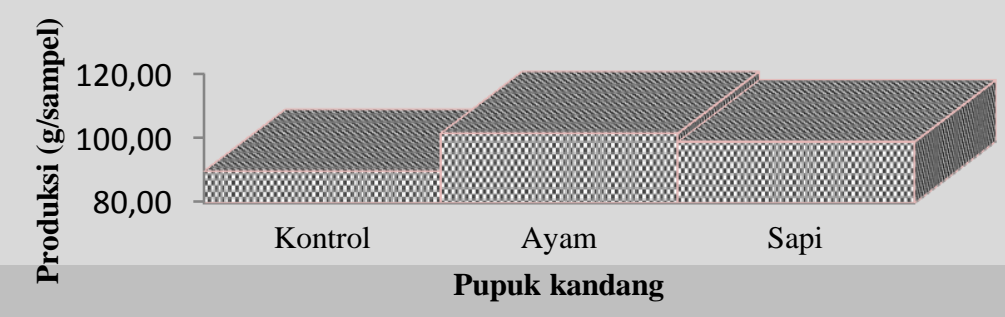

Gambar 4. Rata-rata produksi bit (g/sampel) dari pengaruh pupuk kandang pada saat panen

Dari Tabel 2. Penggunaan pupuk bio-kimia RealStrong pada dosis 375 g/plot (R3) menghasilkan produksi paling tinggi dengan ratarata $104.71 \mathrm{~g} / \mathrm{sampel}$, berbeda tidak nyata dengan dosis yang lebih rendah pada $250 \mathrm{~g} /$ plot (R2) ratarata $103.14 \mathrm{~g} /$ tanaman, tetapi berbeda nyata terhadap penggunaan dosis $125 \mathrm{~g} /$ plot (R1) dan kontrol (R0). Dilihat pada perlakuan kontrol (R0) memberi hasil yang paling rendah rata-rata 85.78 $\mathrm{g} /$ sampel, dengan berbeda tidak nyata terhadap $\mathrm{R} 1$, tetapi berbeda nyata terhadap R2 dan R3. Dari hasil ini diperoleh untuk menghasilkan bit dapat menggunakan dosis $250 \mathrm{~g} / \mathrm{plot}$ (R2) dan merupakan dosis anjuran.

\section{c. Produksi umbi bit (kg/plot)}

Produksi bitdari hasil pengamatan (kg/plot) dilakukan saat panen dengan cara penimbangan masing-masing perlakuan dari pengaruh pupuk kandang (P) dan penggunaan dosis pupuk bio-kimia ( $\mathrm{R}$ ) memberikan pengaruh yang berbeda nyata $(\mathrm{p}<$ 0.05) dari hasil analisa statistik, dan rata-rata produksi bit $(\mathrm{kg} / \mathrm{plot})$ dapat diihat pada Tabel 4.

Dari Tabel 2. dapat diketahui bahwa pengaruh dosis pupuk kandang ayam (P1) merupakan produksi/plot paling tinggi dengan rata-rata 3.05 $\mathrm{kg} /$ plot dengan memberikan produksi yang sama dengan penggunaan pupuk kandang sapi (P2) rata-rata $3.01 \mathrm{~kg} / \mathrm{plot}$, tetapi 
berbeda nyataterhadap produksi kontrol (tanpa pupuk) dengan ratarata $2.67 \mathrm{~kg} /$ plot. Dari hasil (Tabel 2) dapat diketahui untuk mendapatkan produksi bit dapat menggunakan pupuk kandang ayam
(P1) atau kandang sapi (P2). Perbedaan produksi/plot dari pengaruh pupuk kandang dapat dilihat pada Gambar 5.

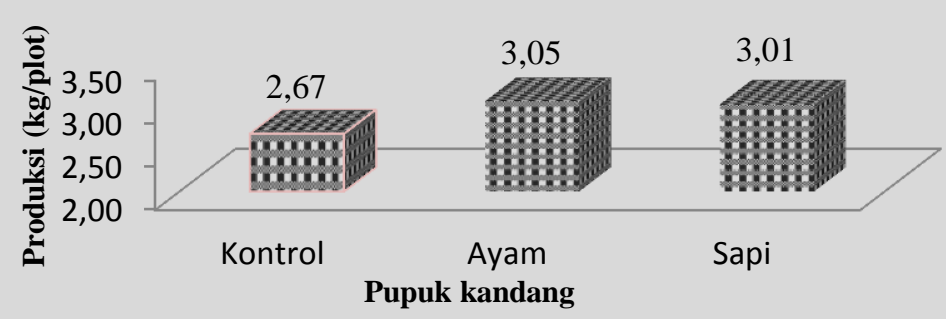

Gambar 5. Rata-rata Produksi bit (kg/plot) dari pengaruh pupuk kandang

Tabel 3. Rata-rata berat krop/plot BitPengaruh Pupuk Kandang dan Bio-Kimia RealStrong (kg/plot).

\begin{tabular}{ccccc}
\hline Perlakuan & Po & P1 & P2 & Rata-rata \\
\hline R0 & 2.32 & 2.73 & 2.57 & $2.54 \mathrm{c}$ \\
R1 & 2.55 & 2.94 & 2.95 & $2.81 \mathrm{bc}$ \\
R2 & 2.75 & 3.28 & 3.25 & $3.09 \mathrm{ab}$ \\
R3 & 3.06 & 3.24 & 3.29 & $3.20 \mathrm{a}$ \\
\hline Rataan & $2.67 \mathrm{~b}$ & $3.05 \mathrm{a}$ & $3.01 \mathrm{a}$ & 2.91 \\
\hline
\end{tabular}

Huruf yang sama pada kolom dan baris rata-rata yang berbeda tidak nyata pada taraf $5 \%$.

Dari Tabel 3. Dapat diketahui bahwa penggunaan pupuk bio-kimia Realstrong (R) pada dosis 375 g/plot (R3) merupakan produksi/plot paling tinggi dengan rata-rata $3.20 \mathrm{~kg} / \mathrm{plot}$ dengan berbeda tidak nyata $(\mathrm{p}<0.05)$ terhadap pengguaan dosis yang lebih rendah $250 \mathrm{~g} / \mathrm{plot}$ (R2) dengan rata-rata $3.09 \mathrm{~kg} /$ plot, tetapi berbeda nyata terhadap perlakuan R1 dan R0. Jika dilihat pada kontrol (R0) merupakan produksi/sampel paling rendah dengan produksi rata-rata $2.54 \mathrm{~kg} / \mathrm{plot}$ dengan berbeda nyata terhadap penggunaan pupuk biokimia (R2 dan R3). Dari hasil analisa ini pada Tabel 3 bahwa untuk mendapatkan produksi ratarata/plot cukup baik dapat menggunakan pupuk bio-kimia pada dosis $250 \mathrm{~g} / \mathrm{plot}$ dan merupakan dosis anjuran.
Perlakuan kombinasi dosis kedua factor pupuk kandang dengan pupuk bio-kimia menunjukkan perbedaan yang tidak nyata $(\mathrm{p}<0.05)$ terhadap pengukuran produksi/plot tanaman bit. Perlakuan kombinasi penggunaan kedua faktor yang diujikan saling interaksi yang mendukung antara satu faktor mendukung dengan faktor kedua.

\section{Pembahasan}

\section{a. Pengaruh Pupuk kandang Terhadap Pertumbuhan dan ProduksiTanaman Bit.}

Hasil pengukuran yang telah dianalisa secara statistik memberikan pengaruh yang berbeda tidak nyata $(\mathrm{p}>0.05$ ) terhadap pertumbuhan tinggi tanaman pada 2 dan 3 minggu setelah tanam (mst), tetapi setelah tanaman berumur 4 minggu tinggi tanaman memberikan pengaruh 
yang berbeda nyata $(\mathrm{p}<0.05$ termasuk produksi bit/sampel atau produksi/plot. Akan tetapi pengaruh yang berbeda tidak nyata terhadap jumlah daun. Pemberian pupuk organik kandang merupakan salah satu faktor dalam meningkatkan ketersediaan hara dalam tanah yang dibutuhkan oleh tanaman selama pertumbuhan dan peningkatan produksi.

Pengaruh pupuk organik kandang ayam (P1) lebih baik digunakan pada tanaman dibandingkan dengan pupuk kandang sapi (P2) baik terhadap pertumbuhan tanaman maupun produksi.Hal ini disebabkan kandungan hara dari kandang ayam lebih tinggi dan lebih mudah terurai dibandingkan denganpupuk kandang sapi(Lingga 1991). Oleh sebab itu hara kandunga pada jenis pupuk menentukan kuantitas pupuk dan sangat penting yang diberikan pada tanaman. Jumlah hara yang diberikan dengan dosis pupuk organik merupakan meningkatkan ketersediaan unsur hara yang dapat diserap oleh akar tanama selama pertumbuhan.

Rendahnya kandungan hara pada pupuk kandang sapi berbandinga pupuk kandang ayam yang diberikan pada tanaman memberi pengaruh terhadap daya penyerapan oleh akar tanaman dan akan mengakibatkan terhambatnya pertumbuhan dan produksi dibandingkan dengan pupuk yang mempunyai kandungan hara yang lebih tinggi.

Novizan (2002) menyatakan bahwa bila tanaman mengalami kekurangan unsure akan mengakibatkan

pembentukanpertumbuhan menjadi terhambat. Selain dari pada kandungan hara dalam pupuk kandang yang berbeda yangdiberikan pada tanaman juga dipengaruhi oleh dosis, waktu pemberian pupuk atau fase tanaman (Sutedjo, 2002). Dengan tingginya hara yang terkandung dalam pupuk kandang akan meningkatkan ketersediaan unsur hara yang tersedia sebagai penambahan unsur hara yang diperlukan bagi tanaman untuk pertumbuhan dan produksi (Lingga dan Marsono. 2004).

Pupuk organik berperan sebagaimeningkatkan hasil pertanian organik secara berkesinambungan sebagai penyubur dan multiguna yang mangandung mikroorganisme (bakteri dan jamur) yang diproses secara sempurna dengan berbagai bahan alami yang berperan dalam pengikatan unsur hara penting bagi tanaman dan berperan meningkatkan kesuburan tanah (Novizan, 2002). Pupuk organik yang berbeda memberikan mengandung jumlah hara yang berbeda begitu pula senyawa bioaktif, hormon pertumbuhan, anti hama maupun vitamin serta diperkaya dengan hara esensial pada pupuk untuk tanaman, (Anonim, 2010).

\section{b. PengaruhDosis Pupuk Bio-kimia Realstrong Terhadap Pertumbuhan dan Produksi Tanaman Bit}

Hasil pengamatan setelah di analisis secara statistik diperoleh pengaruh dosis pupuk bio-kimia Realstrong ( $\mathrm{R}$ ) berpengaruh nyata $(p<0.05)$ terhadap tinggi tanaman setelah umur 4 minggu setelah tanam (mst), produksi/sampel (g)maupun produksi per plot $(\mathrm{kg})$, akan tetapi berbeda tidak nyata $(\mathrm{p}>0.05)$ terhadap pertumbuhan tinggi 
tanaman pada 2 dan 3 mstdan terhadap jumlah jumlah daun. Pemberian pupuk bio-kimia merupakan jenis pupuk organic yang mengandung banyak unsur yang diperlukan oleh tanaman disamping mengandung mikroorganisme dimana salah satu faktor dalam meningkatkan ketersediaan hara bagi tanaman sehingga dapat meningkatkan pertumbuhan tinggi tanaman dan peningkatan produksi. Rendahnya tingkat pemberian unsur hara melalui pemupukan untuk tanaman akan mengakibatkan rendahnya ketersediaan hara dalam tanah dan berakibat terhambatnya pertumbuhan dan perkembangan tanaman sekali gus menurunkan tingkat produksi. Penambahan bahan bio-kimia RealStrong ke dalam tanah mempengaruhi keadaan tanah seperti sifat kimia dan sifat fisika dan biologis tanah. Selain dari pada tanaman kelapa sawit dan respon pada tanaman kubis juga telah telah dilakukan penelitian terhadap tanaman Brokoli (Munthe, 2016)

Ketersediaan unsur hara dan mikroorganisme pada pupuk yang diberikan melalui tanah yang diperlukan tanaman sangat membantu melarutkan zat-zat hara yang tidak larut, menekan petumbuhan organisme tanah yang merugikan (patogen), membantu proses nitrifikasi tanah dan membantu melancarkan aerase atau peredaran udara dalam tanah (Samadi, 1997, Mayadewi 2007; Musnawar, 2003).

Hal ini dapat diketahui bahwapenggunaan pupuk bio-kimia sebagai salah satu usaha untuk meningkatkan produksi tanaman sudah sangat membudidaya dan petani telah menganggap bahwa pupuk dan cara pemupukan sebagai faktor utama dalam pertanian
(Anonim, 2010). Pupuk bio-kimia RealStrong berperan sebagai meningkatkan hasil pertanian organik secara berkesinambungan. Penyubur dari pemberian pupuk biokimia RealStrong multiguna yang berperan dalam peningkatan unsur hara penting dalam tanah bagi tanaman sekaligus berperan dalam meningkatkan kesuburan tanah (Novizan. 2002).Pupuk bio-kimia mengandung berbagai nutrisi, senyawa bioaktif, vitamin serta diperkaya dengan hara esensial seimbang bagi tanaman, bertahan dalam waktu lama' dengan meningkatkan unsur hara penting bagi tanaman (Anonim, 2010).

Pengaruh pupuk bio-kimia membantu meningkatkan kesuburan tanah, mengurangi kerusakan dan serangan penyakit dan membantu menetralkan racun dan memperkuat serta memperpanjang efek pemupukan. Selain dari pada itu pupuk bio-kimiabukan saja berpengaruh pada pertumbuhan dan produksi tanaman juga terhadap pertumbuhan gulma juga akan semakin meningkat dengan tergantung kepada jenis pupuk organiknya. Ketersediaan hara yang lengkap untuk tanaman mempunyai kemampuan yang tinggi dalam meningkatkan pertumbuhan dan produksi tanaman ( Zarwan, dkk. 1994; Mayadewi. 2007).

Pupuk bio-kimia memberikan pengaruh yang cukup tinggi terhadap pertumbuhan dan produksi tanaman dilapangan. Hal ini disebabkan kandungan hara yang terdapat didalamnya bahwa pupuk bio-kimia lebih tinggi kandungan Nitrogen, $\mathrm{P}_{2} \mathrm{O}_{5}$ dan $\mathrm{K}_{2} \mathrm{O}$ nya berbanding dengan jenis pupuk kandang yang berbeda, jika dilihat dari kandungan lainnya terutama pupuk kandang sapi lebih rendah dibandingkan pupuk organik 
dari kandang ayam (Sutejo, 2008; Sarief, 1989). Jenis pupuk organik merupakan pupuk lengkap karena mengandung unsur hara Makro dan Mikro meskipun dalam jumlah tersedia yang sedikit (Zarwan. dkk. 1994). Setiadi (2000) menyatakan bahwa faktor pembatas dalam pertumbuhan dan perkembangan tanaman adalah penyerapan zat hara yang penting (esensial). Dalam proses pertumbuhan tanaman menyerap unsur hara sehingga terjadi proses metabolisme antara lain pertumbuhan sel dipenuhi, disamping itu melalui berat umbi berarti ketersediaan makanan untuk pertumbuhan semakin meningkat.

\section{c. Pengaruh Interaksi Antara Pupuk kandang dengan pupuk bio-kimia Terhadap Pertumbuhan dan Produksi Tanaman Bit.}

Berdasarkan hasil analisa dan sidik ragam menunjukkan bahwa tidak ada interaksi yang berbeda nyata antara perlakuan pemberian pupuk kandang dengan pupuk biokimia RealStrong terhadap pertumbuhan tinggi tanaman dan produksi tanaman bit.Keadaan ini disebabkan karena kedua faktor yang diujikan pada tanaman adalah saling menyokong dalam ketersediaan hara dalam tanah untuk kebutuhan tanaman, oleh karena itu akan berakibat kepada pertumbuhan dan produksi yang semakin besar. Hal ini sesuai dengan Sutopo (1988) yang menyatakan bahwa kesesuaian pupuk yang diberikan pada tanaman mengakibatkan ketersediaan haradalam tanah makin banyak untuk tanaman. Tanaman yang cukup mendapat hara akan mampu meningkatkan pertumbuhan dan produksi, hal ini disebabkan oleh adanya penyerapan air dan hara yang lebih baik. Pertumbuhan dan produksi tanaman baik dari segi kuantitaas maupun kualitas tergantung pada jenis tanah, ketersediaan unsur hara dalam tanah dan banyaknya hara dalam tanah (Nainggolan dan Tarigan, 1992).

Interksai dua faktor yang diujikan memberikan pengaruh yang tidak nyata Hal tersebut bila menunjukan salah satu faktor berpengaruh lebih kuat daripada faktor lainnya, maka pengaruh faktor tersebut tertutupi dan bila masingmasing faktor mempunyai sifat yang jauh berbeda pengaruh dan sifat kerjanya maka akan menghasilkan hubungan yang berpengaruh tidak nyata dalam mendukung suatu pertumbuhan tanaman (Poerwoidodo 1992). Selanjutnya Hakim (1986), menyatakan bahwa pertumbuhan tanaman akan lebih baik bila faktor yang mempengaruhi pertumbuhan seimbang dan memberi keuntungan. Bila faktor ini tidak dapat dikendalikan maka pertumbuhan yang diharapkan tidak dapat diperoleh.

\section{Kesimpulan}

1. Penggunaan pupuk kandang ayam (P1) merupakan jenis pupuk yang tepat bagi pertumbuhan dan produksi tanaman bit.

2. Pengujian Dosis pupuk bio-kimia RealStrong pada $250 \mathrm{~g} / \mathrm{plot}$ (R2) merupakan dosis yang dapat dianjurkan dalam penanaman bit untuk menghasilkan pertumbuhan dan produksi.

3. Interaksi pupuk kandang dengan dosis pupuk organik bio-kimia (PR) tidak berpengaruh interaksi yang nyata terhadap semua perlakuan yang diujikan.

\section{Ucapan Terima Kasih}

Penulis menyampaikan terima kasih 
kepada Ketua LPPM Universitas Quality Ibu Juliana Br. Simbolon yang telah memberikan motivasi sehingga tulisan ini dapat dipublikasikan.Kepada Sri Desi Br. Sinuhaji yang telah mengerjakan tugas-tugas di lapangan sehingga penelitian ini dapat berjalan dengan baik.

\section{DAFTAR PUSTAKA}

Anonimous. 2010. Pemupukan dengan Pupuk Hayati (http://www. Kurnia Press.

com). Deptan Ci No 474/Hayati/Deptan-PPI/I/2010.

Anonim.2010.Tanamanbit.http://id.w ikipedia.org/wiki/bit_(tanama

n).Diaksestanggal 23 september 2017

Fardiaz. 2013. Mikrobiologi Pangan I. Gramedia pustaka Umum, Jakarta.

Hakim, N., Nyakpa, M.Y., Lubis, A.M., Nugroho, S.G., Diha, M.A., Hong, G.B.,Bailey, H. 1986. Dasar-Dasar Ilmu Tanah. Universitas Lampung. 488 hal.

Handayani, I. 2011. Kenalan dengan Buah

Bit.http://kesehatan.koMPa.siana. com. (26 Juni 2014).

Hardjowigeno, S., 2003. Ilmu Tanah, Akademika Presindo, Jakarta.

Lingga .1991. Petunjuk Penggunaan pupuk. Penebar Swadaya Jakarta.

Lingga dan Marsono, 2004. Petunjuk Penggunaan Pupuk, Redaksi Agromedia,

Jakarta.

Munthe, K. P. 2016. Pengaruh Pemberian Pupuk Organik Realstron Terhadap Pertumbuhan Tanaman Brokoli. Stevia ISSN No. 2087-6939 Vol VI No.1Januari 2016.

Musnamar, E. I. 2003. Pupuk
Organik Padat: Pembuatan dan Aplikasinya. Jakarta: Penebar Swadaya

Mayadewi N.N.A. 2007. Pengaruh jenis pupuk kandang dan jarak tanam Terhadap Pertumbuhan Gulma dan Hasil jagung manis (Tesis). Fakultas Pertanian Universitas Udayana. Den Pasar Bali, Indonesia.

Marsono, 2004. Pupuk Akar, Produksi Agro Media. Jakarta.

Meridianto.2013, Jurnal Teknologi Pertanian. Vol 8 No 3 ( 2013) 172181.

Nainggolan P. dan D. Tarigan. 1992. Pengaruh Sumber dan waktu pemberian pupuk kalium. Terhadap Hasil dan Mutu Umbi Kentang. Dalam : Jurnal Hortikultura 2

Nottingham, S. 2004.

Beetroot.http://ourworld.com puserve.com/ homepages/

Stephen-Nottingham. 28 Mei 2009

Novizan, 2002. Petunjukan Pemupukan yang Efektif. Agro Media pustaka, Jakarta.

Pitalua, E., Jimenez, M., VernonCarter, E. J., Beristain, C. I. (2010). Antioxidant activity of microcapsules with beetroot juice using gum Arabic as wall material. Journal Food and Bioproducts Processing, 88, 253-258 Poerwowidodo. 1992. Telaah Kesuburan Tanah. Angkasa, Bandung.

Sarief, E. S. 1989. Kesuburan dan Pemupukan Tanah Pertanian. Pustaka Buana.

Bandung.197 hal.

Setiadi. 2000. Bertanam Cabai .

Penebar Swadaya. Jakarta.

Strack et al., 2002, (*) Canadanovic 2011. agrofokus.blogspot.com/mak 
alah-budidaya-tanaman-bitmerah-beta.(17 November 2017)

Sunarjono, H., 2004. Bertanam 30 Jenis Sayuran. Penerbit Penebar, Jakarta.

Sutopo. 1988. Pengantar Penelitian Kualitatif Dasar- dasar Teori Dan Peraktis., Surakarta: UNS Press

Stell, R, G, D. dan J. H. Torrie. 1993. Prinsip Dan Prosedur Statistika (Pendekatan Biometrik) Penerjemah B Sumantri. Jakarta. Gramedia Pustaka Utama.

Sutedjo, M. M. 2008. Pupuk dan cara Pemupukan. Rineka Cipta. Jakarta.

Widhiana E., 2000. Ekstraksi Bit (Beta vulgaris I. var. rubra I.) sebagai Alternatif

Widodo. 2008. Pupuk Organik dan Pupuk Hayati. Jawa Barat: Balai Besar Penelitian dan Pengembangan Sumberdaya Lahan Pertanian.Jakarta.

Zarwan, Syahril, \& Mulyono. 1994. Studi pertumbuhan gulma pada beberapa jenis pupuk kandang. Prosiding Konferensi XII Himpunan Ilmu Gulma

$\begin{array}{ll}\text { Indonesia. } & \text { Padang } \\ \text { Sumatera Utara. } \\ 5 \text { hal }\end{array}$

